\title{
An Efficient Query Processing Data Structure for Moving Objects using Information of Future Positions

\author{
— High Performance Data Access by Direct Indexing-
}

\author{
Hiroyuki Dekihara Member (Hiroshima International University, h-dekiha@it.hirokoku-u.ac.jp) \\ Yasuaki Nakamura Non-member (JDCRI, and TTT Co., Ltd., ynk@ieee.org)
}

Keywords : spatial search, spatial data, spatial data structure, moving object, navigation, direct indexing

We propose a novel data structure, called the DIMD-tree, that provides efficient successive spatial searches in GPS navigation systems, mobile phone system and so forth. The DIMD-tree can be applicable for the geographic data management of positioning systems as well as the query processing for the current and anticipated future positions of moving objects. The performances of the DIMD-tree are evaluated by simulation tests.

Consider a mobile phone with GPS function. Users request for some sever to download map data close to a location of each user. When a user moves to some location outside the area where map data were downloaded, a mobile terminal does not have so much memory that a server must send map data around the new location (Fig.1.). In the servers, a spatial data structure is utilized to perform quick retrieval of map data around the requested location. In GPS navigation, we can assume the successive request locations are not so far from the former location. Usually, data searches using the hierarchical data structure ( tree structure) are performed from the root of the tree. Successive query locations are close each other so that we can reduce the searching time to use the former result. In other words, in the case of GPS navigation, retrieving is not performed from the root node but from a node that includes the former requested area and predicted area. To realize this idea, a spatial data structure and retrieving algorithm are developed.

To perform current or future spatial queries efficiently, we develop the DIMD-tree by extending a balanced hierarchical data structure for multi-dimensional data, called the MD-tree. The basic idea introduced in the DIMD-tree is direct indexing into a node or leaf which includes the predicted positoin of a moving object, and the bi-directional link between nodes in a tree (Fig. 2.). A moving object has a pointer to a node or leaf whose corresponding region includes the former location and predicted location. In the search processing, the searching performs from this node or leaf. If a query area is outside the region predicted,

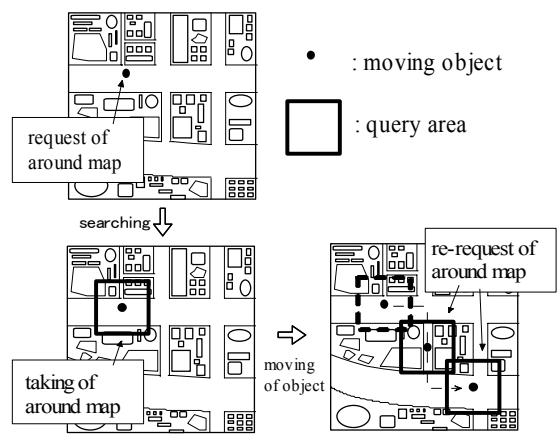

Fig. 1. Queries from moving object the search process retrieves sibling nodes and a parent node, recursively. Therefore, the search process of the DIMD-tree retrieves a close area to the former query location, and then the retrieving area is enlarged by going up the tree. In the Fig.2., objects, $\mathrm{A}, \mathrm{B}$, and $\mathrm{C}$, have pointers to leaf $\mathrm{L} 1$, internal node $\mathrm{I} 2$, and root $\mathrm{R}$, respectively, because the area of anticipated future positions are enclosed the management regions of L1, I2 and R. Therefore, the search processing for a successive query from A, B and $\mathrm{C}$ are performed from $\mathrm{L} 1, \mathrm{I} 2$ and $\mathrm{R}$, respectively.

Fig.3 shows the results of spatial searches. The numbers of maximum child nodes of the DIMD and MD trees are equal to 3, and number of objects in a leaf is set to 20 in the following experiment. 200,000 objects are inserted into $10,000 \times 10,000$ square area in the data structure. The number of moving objects is $10 \%$ of objects in data structure. The numbers of visited nodes in the DIMD-tree are $2 \%-40 \%$ less than the numbers of visited nodes in the MD-tree. The numbers of visited leaves in the DIMD-tree are equal to the numbers of visited leaves in the MD-tree. The searches of the DIMD-tree are much faster than the MD-tree when the speeds of moving objects are slow.
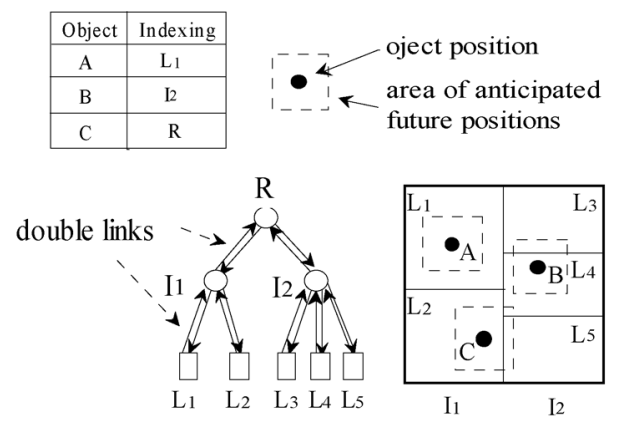

Fig. 2. An example of a simple DIMD-tree

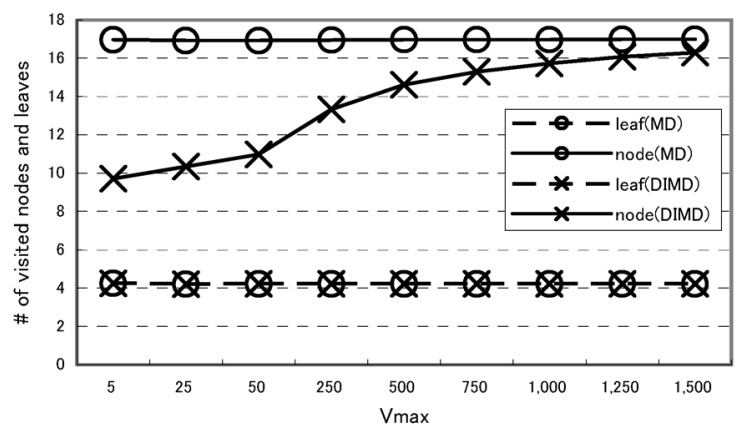

Fig. 3. Search performances of the MD-tree and the DIMD-tree (without expectation error) 


\title{
予測位置情報を利用した移動オブジェクトからの空間検索を
}

\section{効率的に実行する空間データ構造}

一直接参照によるデータアクセスの高速化——

正 員 出木原裕順* 非会員 中村 泰明**

\section{An Efficient Query Processing Data Structure for Moving Objects using Information of Future Positions \\ — High Performance Data Access by Direct Indexing- \\ Hiroyuki Dekihara*, Member, Yasuaki Nakamura**, Non־member}

\begin{abstract}
We propose a novel data structure, called the DIMD-tree, that provides efficient successive spatial searches in GPS navigation systems, mobile phone systems and so forth. The DIMD-tree can be applicable for the geographic data management of positioning systems as well as the query processing for current and anticipated future positions of moving objects. The basic idea introduced in the DIMD-tree is direct indexing into a node or leaf which includes the predicted position of a moving object. The performances of the DIMD-tree are evaluated by simulation tests.
\end{abstract}

キーワード : 空間検索，空間データ，空間データ構造，移動オブジェクト，ナビゲーション，直接参照

Keywords : spatial search, spatial data, spatial data structure, moving object, navigation, direct indexing

\section{1. はじめに}

地理情報システム（GIS：Geographic Information Systems) や全地球測位システム (GPS: Global Position System ），高度道路交通システム（ITS：Intelligent Transport Systems), 追跡制御システムなどの分野では, 時空間データ構造の重要性が高まっている(1) (4)。特に, 携 帯電話や PDA（Personal Digital Assistants）などの携帯 情報端末の発展に伴い，無線通信技術を利用した位置情報 システムでは, 高度なアプリケーションの実装や各種サー ビスの提供が可能になっており (5), それらの移動情報端末の データ（移動オブジェクト）を効率的に管理可能な時空間 データ構造が要求されている(6) (10)。一般に, 移動オブジェ クトの時系列的な位置変化に着目した場合，現在時刻の移

* 広島国際大学工学部情報通信学科

干737-0112 広島県只市広古新開 5-1-1

Department of Information Technology, Hiroshima International University,

5-1-1 Hiro-koshinkai, Kure, Hiroshima 737-0112

** 日本情報通信研究開発機構

干105-0001 東京都港区虎ノ門 1-21-8

Japan Data and Communication Research Institute

1-21-8, Toranomon, Minato-ku, Tokyo, 105-0001

T.T.T.(株)

干170-0005 東京都豊島区南大塚 2-37-5 MSB-21

Tokyo Head Office, T.T.T. Co., Ltd.

2-37-5, Minami-Otsuka, Toshima-ku, Tokyo, 170-0005
動オブジェクトの管理の他に大きく分けて 2 つの課題ある。 一つは，移動オブジェクトを現在の位置だけでなく，未来 の位置を予測して管理・利用することである。もう一つは, 移動オブジェクトが過去に移動した履歴や軌跡を管理・利 用することである。本稿では, 前者の課題, 特に予測され た位置情報に基づいて移動オブジェクトとデータ構造との データアクセスの高速化に焦点を当てている。例えば, GPS 機能が付属した携帯電話やPDAなどの移動情報端末の使用 を仮定した場合，ユーザが周辺の地図情報を閲覧するため に, すなわち, ユーザの現在位置を基準点とした近接範囲 の地理情報を閲覧するために, 地図情報を管理しているデ ータベースサーバヘ地図情報のデータのダウンロードを要 求する状況が考えられる。移動情報端末の記憶領域には限 界があるため, このときダウンロードされる地図情報は限 られた範囲になる。ダウンロードされた地図情報の範囲の 外へユーザが移動した場合, 言い換えると, 新しい範囲の 地図情報を閲覧したい場合，ユーザは再びサーバヘダウン ロードを要求し，サーバはユーザの現在位置周辺の新しい 地図情報を端末へ送らなければならない。サーバ側では, 要求された位置の周囲の地図情報を高速で空間範囲検索す るために, 空間データ構造が利用されている。GIS アプリ ケーションやGPSナビゲーションなどの位置情報システム において，ある移動オブジェクトから連続的に空間範囲検 
索の要求が出された位置は, 以前に要求が出された位置か らそれほど離れてはいないと考えられる。通常, 木構造（階 層型データ構造）を利用した空間範囲検索では，木の根か らノードをたどって葉まで探索される。しかし，検索を常 に根から実行するのではなく, 移動オブジェクトのパラメ 一タや属性值などから移動オブジェクトの移動先をあらか じめ予測しておき，検索時にはオブジェクトのデータが格 納されている葉やその部分木を直接的に探索できれば，検 索の高速化が計れると考えられる。この概念の実現のため に，新しいデータアクセス方式を開発した。

本論文では, 提案方式を採用した新しいデータ構造とし て, DIMD 木 (Direct Indexing MD-tree) を提案する。GPS ナビゲーションでは，移動情報端末の地図情報のデータは， 現在位置に従って頻繁に更新されなければならない。端末 一送られて更新される地図情報のデータは, データ容量が 小さく, 更新プロセスも短時間の方が望ましい。この問題 を解決するために, 多次元完全平衡木である空間データ構 造 MD 木（Multi-Dimensional tree）（11)を改良した DIMD 木を新しく提案する。DIMD 木は，携帯情報端末などのエ ンドユーザ（すなわち，移動オブジェクト）の移動先を予 測し，予測された位置を管理領域内に含んでいるノードや 葉へ直接アクセス（直接参照）を可能としている。DIMD 木は，静的オブジェクトのみをデータ構造内に管理してお り，移動オブジェクトの動きを予測する関数や任意に設定 された移動特性情報などから提供された未来位置情報を利 用して，移動オブジェクトからの静的オブジェクトへのデ ータアクセスの高速化を図った空間データ構造である。

DIMD 木の構造は, Bentley が提案(15) した木構造の枝 (す なわち，ノード間のポインター) を双方向にリンクさせた ものと同じ構造概念を成している。Bentleyの方式は，デー 夕構造（木構造）に保存されている（点）データを指定し た検索や削除の場合，そのデータを含む葉への直接参照を 可能とし，さらにその葉からの Bottom-up 検索を提案して いる。しかし，内部ノードへの直接参照は提案されていな いだけでなく，任意の位置を指定した場合の検索や移動才 ブジェクトの位置に基づく空間検索への応用は考えられて いない。シミュレーション実験より，本論文での提案方式 である DIMD 木は，MD 木や Bentley の方式などの従来法 よりも空間検索の高速化が可能であることを示すと共に, その性能は，未来位置情報の正確性に依存するものの，た とえ未来位置情報に誤差があったとしても，最悪でも従来 法と同程度であることを示す。

本稿では，まず移動オブジェクトの管理と DIMD 木の基 となった MD 木について簡潔に述べ, 次に DIMD 木の概念, データ構造，およびアルゴリズムについて説明する。さら に，シミュレーション実験により DIMD 木の有用性につい て検討し，最後にまとめで総括する。

\section{2. 空間データ構造と移動オブジェクトの管理}

人物や車両，航空機などの移動オブジェクトや道路や川,

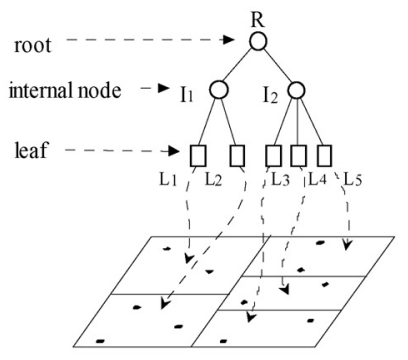

(a) an example MD-tree

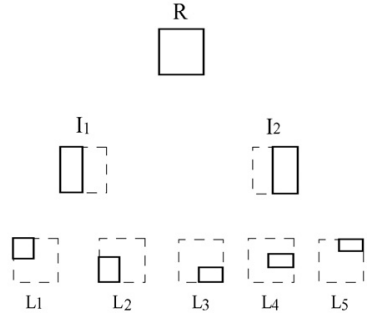

(b) management of regions
図 $1 \mathrm{MD}$ 木の例

Fig. 1. An example of the MD-tree.

建物などの移動しない静的なオブジェクトを管理するため に，数多くの階層的な空間データ構造が提案されてい る(11) (14)。その中でも, MD 木は, 効率的な空間オブジェク トの管理が可能なデー夕構造の一つである。図 1 に, MD 木の例を示す。この章では, まず, DIMD 木の基となった $\mathrm{MD}$ 木のアルゴリズムについて簡潔に述べる。そして, 移 動オブジェクトの管理と GPS ナビゲーションにおける空間 範囲検索について述べる。

〈2·1〉 MD 木 まず, MD 木のデータ構造について簡 単に示す。図 1 は $\mathrm{MD}$ 木の例である。 MD 木は, 内部ノー ドと葉ノードの 2 種類のノードで構成されており, オブジ エクトのデータは葉のみに格納される(なお, 内部ノード を以下，単にノードと呼ぶ)。それぞれのノードは長方形に 対応しており，根は全データ領域と対応している。子ノー ドは, 親ノードの部分領域に対応している。もし仮に, オ ブジェクトのデータがすでに満杯に格納されている葉 $\boldsymbol{L} に$, 新しいオブジェクトのデータが挿入される場合, $L$ に含まれ ていたオブジェクトのデータが少なくとも半分ずつ含まれ るように, 挿入された領域が 2 つの部分領域に分割される。 処理プロセスの流れとしては，まず， $L$ が 2 つに分割され た部分領域の一つに対応するように更新され，もう一方に は, 対応する新しい葉を作り, $L$ から新しい葉の管理領域に 含まれているデータを新しい葉へ移動させる流れになる。 $\mathrm{MD}$ 木の特徴としては, 常に完全平衡木となり, そのメモ リ効率（葉のデータ占有率）は $66.6 \%$ 以上になる。 MD 木 のアルゴリズムの詳細については，文献(11)に詳しい。

〈2·2〉移動オブジェクトから空間データへのデータア クセス GISアプリケーションやGPSナビゲーションで は，道路や川，建物などといった地理情報は，短期間では 変化しない静的なデータと見なせる。したがって, これら の静的なデータは, 空間データ構造によって管理される。 例えば，携帯電話などの移動情報端末を使用するユーザと 地図情報の閲覧サービスでは，ユーザが移動オブジェクト (クライアント) であり, サービスを提供する側がデータ構 造（サーバ）となる。図 2 に移動オブジェクトからの空間 範囲検索の流れを示す。ユーザが周辺の地図情報を閲覧し たい場合, ユーザは現在位置をデータ構造に送信する（図 2 左上参照)。データ構造は, ユーザの現在位置を基準にして 空間範囲検索を行い，その結果をユーザに返すことで，ユ 


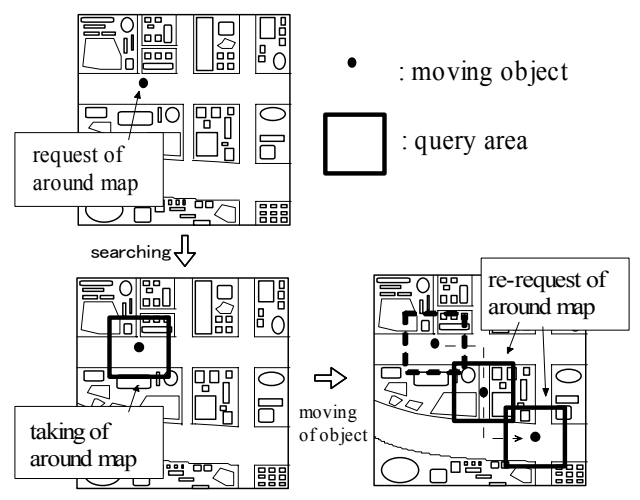

図 2 移動オブジェクトからの空間範囲検索

Fig. 2. Queries from a moving object.

一ザは周辺地図情報の取得が可能となる（図 2 左下参照）。

図 2 右下のように, 取得していた地図の範囲外にユーザが 移動した場合は, その都度, 現在位置をデータ構造に送り 周辺地図の情報を再取得する。このようなサービスにおい ては，移動オブジェクトの現在位置の情報を必ずしもサー バ側で管理する必要はない。ただし，位置の追跡が必要に なるモニタリングシステムなどは，サーバ側で移動オブジ エクトの位置を管理する必要がある。

本研究では, 特に検索性能の高速化に着目寸るため, 移 動オブジェクトの位置情報をサーバ側で管理する必要が無 い状況を想定している。なお，サーバ側で移動オブジェク 卜を管理させる場合においても，提案法を適用することは， 理論的に可能である。

\section{3. 提案方式：空間データ構造 DIMD 木}

DIMD 木は, 携帯電話やPDA などの移動情報端末におけ る GPS ナビゲーションにおいて, 効率的に連続的な空間範 囲検索を実行する。DIMD 木は，移動オブジェクトの現在 の位置, もしくは, 予測された未来の位置を効率的に検索 できるように MD 木を拡張したデータ構造である。DIMD 木の基本的なアイデアは, Bentley の提案している木に保存 されているデータからの葉への直接参照ではなく, 移動才 ブジェクトからの Query（空間検索）を効率的に実行する ために，次期移動位置を予測し，その位置を含む葉やノ一 ドへの直接参照を可能にしている点である。図 3 は, 簡単 な DIMD 木の例である。以下，DIMD 木の概念と構造，構 築法，および検索のアルゴリズムについて述べる。

〈3・1〉 直接参照と双方向リンク枝 DIMD 木は，移 動オブジェクトに，ノード，もしくは葉を直接指し示した ポインターを渡し，移動オブジェクトはこのポインターを 保持する。このポインターを直接参照と呼ぶ。直接参照は, 移動オブジェクトが次の時刻に存在していると予測される 範囲を管理しているノードや葉，言い換えると，次の空間 範囲検索の対象となる部分木の根を指し示している。次の 検索時に検索対象として必要になる部分木を予測し，その 部分木の根から検索プロセスを開始させることで検索時間 の短縮化を実現している。なお，直接参照の初期設定は木

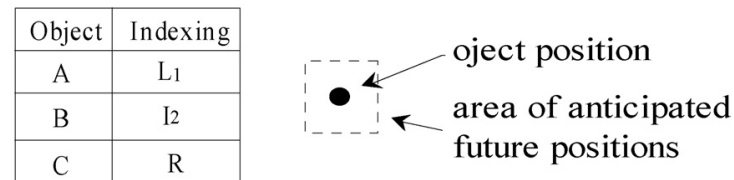

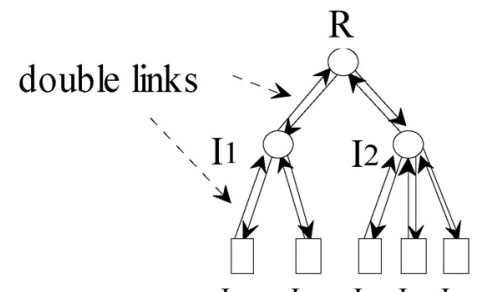

$\mathrm{L}_{1} \quad \mathrm{~L}_{2} \quad \mathrm{~L}_{3} \mathrm{~L}_{4} \mathrm{~L}_{5}$

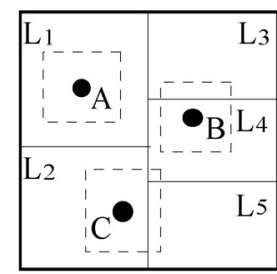

I 1
I2
図 3 DIMD 木の例

Fig. 3. An example of a simple DIMD-tree.

全体の根を指し示しており, 移動オブジェクトからアクセ スがあると（空間範囲検索の要求があると）, 次の検索に備 えて直接参照先を更新して待機しておくことになる。また， DIMD 木のノードと子ノードを接続する枝（ポインター） は, 従来法である Bentley でも提案されているように双方 向のリンクにする。もし仮に, 予測していたノードの範囲 外に移動オブジェクトが移動していた場合，すなわち，， ードや葉の管理領域外を検索しなければならない場合，予 測していたノードの親ノードにさかのぼって兄弟ノードな どを探索することで，より広範囲の領域を管理している部 分木に対して空間範囲検索を実行する。よって, DIMD 木 の探索プロセスは，木を上下し，最悪の場合では，末端の 葉から最上部の根までさかのぼって検索することになる。 しかし，最悪の場合だとしても，根までさかのぼった後は， 通常の根からの検索と同様のプロセスとなる。

連続的な空間範囲検索の要求がない場合, 例えば, トン ネルなどで電波が届かずにアクセスできなかった場合や目 的の検索が完了した場合などは，直接参照を初期值である 木全体の根に再設定しておくことで，検索の非効率化（直 接参照先の範囲外の検索）を抑えることが可能である。ま た, 移動オブジェクトの未来の位置の予測は, 現在位置, 速度, 角度, および方向などの各種パラメータや数式, 関 数などによって導出されるものとする。

なお, Bentleyの方式では, 木構造に保存されているデー タが，どの葉に保存されているかを示す配列を用意するこ とで, 各葉への直接参照を実現している。これは，木構造 へのデータ追加時にそのデータが所属する葉への参照を記 憶することで実現されている。したがって, Bentley の Bottom-up 検索は, 常に葉から検索が開始される。検索処 理は, 直接参照先の葉を探索した後, 適切な頂点ノードま で親ノードをたどりつつ，たどったノードの兄弟ノードに 対して通常の検索 (Top-down 検索) を行うことで実現され る。なお， 4 章のシミュレーション実験において, DIMD 木 の検索と Bottom-up 検索の比較評価を行う。

$\langle 3 \cdot 2\rangle$ 内部ノードと葉の構造 内部ノード $I$ の構造 を以下に示寸。 


\section{$I=\left\{R_{m}, P[K], R_{c}, P_{t}\right\}$}

$R_{m}$ は，Iの子ノードの管理領域を包含する最小の長方形 である。 $P[K]$ は，子ノードへのポインター配列である。な お, $\mathrm{MD}$ 木が 2-3 木の構造を基にしていることから, 最大子 ノード数 $\boldsymbol{K}$ は 3 である。 $\boldsymbol{R}_{\boldsymbol{c}}$ は， $\boldsymbol{I}$ 以下の部分木が管理して いるオブジェクトを包含する最小の長方形（Bounding Box）である。そして， $P_{t}$ は親ノードへのポインターである。 次に，葉 $L$ の構造を以下に示す。

\section{$L=\left\{R_{m}, D[C], R_{c}, P_{t}\right\}$}

$R_{m}$ は， $L$ の管理領域である。 $D[C]$ は，オブジェクトデ ータへのポインター配列である。なお， $C$ はバケット容量 と呼ばれる正の整数でブロックサイズ等から決定される。

$R_{c}$ は， $L$ に格納されているオブジェクトを包含する最小の 長方形 (Bounding Box) である。そして，Pt親ノードへ のポインターである。DIMD 木では, MD 木の内部ノード と葉の構造に新しく親ノードへのポインターである $P_{t}$ を 追加している。なお， $R \boldsymbol{c}$ は，検索時に検索範囲と比較する ことで検索性能の向上に寄与している。

〈3·3〉 構築 法 DIMD 木の構築法は, 木の親ノー ドとその子ノードを双方向で連結する点を除けば，基本的 に MD 木と同様である。ただし，本論文で採用している MD 木は，すべてのデータが一括で与えられたケースである。 $\mathrm{MD}$ 木にデータが一括で与えられた場合は, $\mathrm{kd}$ 木と同様に, データを $\mathrm{x}$ 軸，y軸で順にソートし，左右（上下）の領域の データ数が等しくなるように領域を再帰的に分割し, 領域 のデータ数が，バケット容量以下になるまで繰り返す。そ の時の分割領域を MD 木のノードに対応させ，領域を管理 する。このように構築された MD 木は, 最適な平衡木であ り，各ノードの管理領域は長方形領域を形成し，兄弟ノー ドの管理領域がオーバーラップすることはない。一般に, 空間データ構造の親ノードとその子ノードを連結している リンク，すなわち木の枝は，親ノードからその子ノード（も しくは，葉）への一方向のポインターである。DIMD 木に おいて，木の枝は，双方向のリンクであり，一つが親ノー ドからその子ノード（もしくは，葉）へのポインターであ り，もう一つが子ノード（もしくは，葉）から親ノードへ のポインターである。DIMD 木の構築アルゴリズムは，木 の枝を双方向にするように MD 木の構築アルゴリズムを変 更することで実現できる。また，DIMD 木の削除アルゴリ ズムも構築アルゴリズムと同様に，枝を双方向に変更する 部分を除けば MD 木と同じである。 MD 木の構築・削除ア ルゴリズムの詳細については，文献(11)に詳しい。

〈3・4〉＼cjkstart検索アルゴリズムＤIMD 木において, 移動 情報端末などのクライアントからサーバへの検索要求に は，3つの種類がある。1つ目は，現在位置において最初の 地図情報を要求する初期検索である。2つ目は, 以前に要求 された位置の周辺の地図情報を要求する連続的な検索であ る。最後に, 3 つ目は, 以前に要求された検索とは関連のな い独立検索である。初期検索では, サーバ側はクライアン
トについての情報をもっておらず，クライアント側もサー バの情報をもっていないため, DIMD 木は, MD 木と同様 の空間範囲検索を実行する。連続的な検索では, それ以前 の検索要求の情報が利用される。連続的な検索の場合, そ れ以前に検索要求のあったクライントの位置からそれほど 遠くは離れていないことから，根からではなく予測された ノードから検索を始める。クライアントは, それ以前の位 置から遠く離れた場所の地図情報を要求することも可能で ある。これが独立検索である。また, 電波不良などの理由 により, クライアントがサーバにアクセスできないなどの 特殊な場合にも, 独立検索が実行される。DIMD 木は, こ れらの検索を効率的に実現する。以下に, クライアントの 位置や速度, 角度などの情報をサーバ側で保持しない方式 での検索アルゴリズムについて示す。

初期検索は, 従来の MD 木と同様のアルゴリズムで実施 する。初期検索の後に, 移動オブジェクトは, 現在の位置 や予測された未来の位置を包含する領域を管理しているノ ードや葉へのポインターを保持することになる。連続的な 検索プロセスは，これらのポインターが示すノードや葉か ら開始する。図 3 において, オブジェクト $A, B$, および $C$ は, 次に移動すると予測される領域を管理している葉 $L_{1}$, 内部ノード $I_{2}$, および根 $R$ 一のポインターをそれぞれ保持 している。したがって, $A$ から連続的な検索が要求された 場合，検索プロセスは $L_{1}$ から開始される。 $B$ の場合は， $I_{2}$ を根とした部分木, すなわち, 葉 $L_{3}$ と葉 $L_{4}$ に対して検索が 実行される。一方， $\boldsymbol{C}$ の場合は，根 $\boldsymbol{R}$ から実行される。根 からの検索とは, すなわち $\mathrm{MD}$ 木と同等の検索効率を意味 している。しかしながら，もし仮に，オブジェクトの実際 の位置が予測された位置よりも大きく離れていた場合,

DIMD 木の検索プロセスは親ノードにさかのぼってから実 行されなければならないため, DIMD 木の検索効率は MD 木よりも悪化してしまう可能性がある。例えば，葉から根 までさかのぼった後に MD 木と同等の検索を行った場合,

DIMD 木の検索性能は，MD 木より悪化してしまう。しか し，このようなオブジェクトに関しては，例外として予測 先ではなく根から検索を開始させれば，最悪でも MD 木と 同等の検索性能が保証されることになる。このように, DIMD 木の検索プロセスは，木構造を上にたどった後に下 にたどる場合もある。

図 4 にDIMD 木の検索プロセスの概要を示す。まず初期

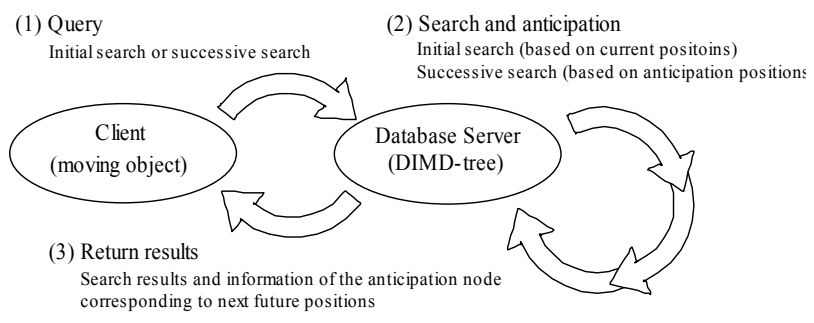

図 4 検索プロセスの概要

Fig. 4. Schema of search processing. 


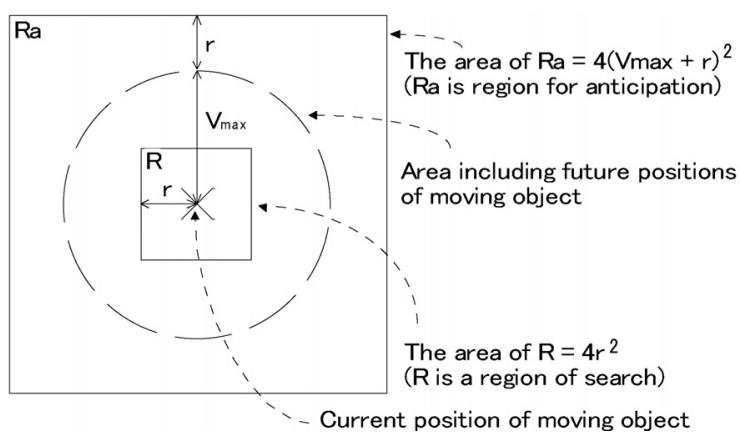

図 5 検索範囲と予想範囲の関係

Fig. 5. A relationship of the search area and the anticipated region.

検索の要求が, クライアント（移動オブジェクト）の移動 情報端末から DIMD 木によって構築されたデータベースサ 一バへ送られる（図 4(1)参照)。データベースサーバは, ク ライアントの現在の位置に基づいて検索を実行する。この 検索の実行と共に, 次にクライアントから要求がある位置 を予測して，連続的な検索の際に利用されるノードを特定 しておく（図 4(2)参照)。このノード情報は，検索結果と共 にクライアントに送信し，クライアントに保持させること も可能である。また，サーバで一括して管理することも可 能である。そして, 検索された地図情報が結果としてクラ イアントに返信され，データベースサーバは，次回の連続 的な検索の待機状態となる。(図 4(3)参照)。

なお，予測プロセスにおいて，移動オブジェクトの未来 の位置は, 移動オブジェクトの各種パラメータや数式, 関 数などから導出する。図 5 に検索範囲の領域と予測された 未来の位置を包含する領域の関係を示す。クライアントの 現在位置から要求された空間検索の領域を $\mathrm{R}$ とする。ただ し， $\mathrm{R}$ はクライアントの現在の位置を中心とした一辺の長 さを $2 \mathrm{r}$ とする正方形であり, その面積 $\mathrm{AR}$ は次式(1)で表わ される。

$$
A_{R}=4 r^{2}
$$

また, 連続的な検索時に使用される直接参照先のノード を判定するための領域, 言い換えると, 移動オブジェクト の予測される未来の位置のすべてを包含する範囲と検索範 囲を合計した領域を Ra とする。 Ra の面積 $\mathrm{A}$ Ra は, 移動才 ブジェクトの移動速度の最大值を $\operatorname{Vmax}$ とすると次式で表 わされる。

$$
A_{R a}=4(V \max +r)^{2}
$$

この Ra とノードの管理領域を比較して, 次回の連続的な検 索時に検索対象となる可能性の高い木構造内の部分木を見 つけ出す。この部分木の根を連続的な検索のための予測さ れた内部ノード Io とする。空間範囲検索のアルゴリズムを 以下に示す。
Node *InitialSearch(R, Ra)

/* 初期検索。なお， $\mathrm{R}$ は検索範囲， $\mathrm{Ra}$ は予測位置十検 索の範囲。また, Io は予測位置に対応するノード, もし くは葉へのポインター, D は外部変数（Global 変数） * $\mathrm{S} 1: \mathrm{In} \leftarrow$ 根, Io $\leftarrow$ NULL.

S2 : Io Search(In, R, Ra)を実行する.

S3 : Return Io.

\section{Node *Search(In, R, Ra)}

/* 空間範囲検索の領域 $\mathrm{R}$ 内のオブジェクトを検索 */

$\mathrm{S} 1$ : In が葉ならば, 葉の中から R 内に存在するオブジェ クトのデータを D に登録する。

$\mathrm{S} 2$ : そうでなければ, In の子ノードから $\mathrm{R}$ と重なる管理 領域をもつノードを In'にセットし，Io〔Search(In', $\mathrm{R}, \mathrm{Ra})$ を実行する.

S3 : Io Anticipation(In, Ra)を実行する.

S4 : Return Io.

Node *Anticipation(In, Ra) /* Io を導出 */

S1 : Io が NULL ならば次の処理を実施する.

$\mathrm{S} 2$ : In の子ノード Ic を調べ, Ic の兄弟ノードの管理領域 が Ra と交差せず,かつ Ic の管理領域が Ra を完全に 包含する唯一のノードならば, Ic を Io にセットして, Return Io.

S3 : Io が NULL でないならば次の処理を実施する.

S4 : In の子ノード Ic を調べ, Ra と管理領域が交差する ノードが 2 つ上あるならば, In を Io にセットして, Return Io.

Node *SuccessiveSearch(R, Ra)

/* InitialSearch( )以降の連続的な検索 */

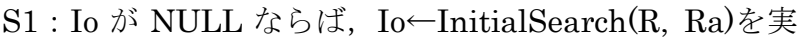
行して終了する.

そうでなければ, In Io.

S2：もし In の管理領域に R が包含されていなければ，Io $\leftarrow$ InitialSearch(R, Ra)を実行して終了する.

S3 : Io Search(In, R, Ra)を実行する.

S4 : Io の管理領域に Ra が完全に包含されていなければ, Io の親ノードたどり，Ra を完全に包含する管理領域 をもつ内部ノードを探し，その内部ノードをIo とす る. †

S5 : Return Io.

初期検索では，InitialSearch( )が実行される。なお，連 続的な検索のための直接参照ノードを決定するための予測 範囲 Ra は, クライアントが保持している速度パラメータか

†すべてのデータが一括で与えられた場合の MD 木では, 領域 分割時に兄弟ノードの領域が重なりを持たないように構成さ れるため, このアルゴリズムでデータの検索漏れはない。 
らあらかじめ導出して与えるものとする。 $\mathrm{R}$ は要求された 検索範囲の大きさであり, Io は連続的な検索のための直接 参照先のノードであり, 初期検索の際には NULL となる。

InitialSearch()にて実行される Search()において，オブジ エクトの検索が実行される。この検索アルゴリズムは, Anticipation( )が実行される部分を除いて, 従来の MD 木と ほぼ同じであり，検索 Query に該当するデータを D に登録 してユーザに返す。なお，Io は関数の戻り值として返す。 Anticipation( )は，再帰的に呼び出された Search( )を抜け る際に,ノードの管理領域と予測範囲 Ra を比較して直接参 照先のノードIo の決定を行い，Io を戻り值として返す。Io が NULL である場合は, Anticipation( )が呼び出されたノ ードInの子ノードの内で, Ra を完全に包含するノードが 1 つ存在し, かつそのノードのほかの兄弟ノードが Ra と交差 しなければ，その子ノードをIo とする (S1-2 参照)。その 条件に当てはまるノードが存在しなければ，Io は NULLの ままとし，そのとき呼び出された Anticipation( )は終了す る。そして, 親ノードで Anticipation( )が呼び出された際に, 再度 Io の決定を判定する。また, 一度 Io が決定している場 合，すなわち Io が NULL でない場合には，Io から根のパ ス上のノード以外で， Ra と交差する兄弟ノードが存在する かどうかの判定を行う（S3-4 参照）。なお， S2 および $\mathrm{S} 4$ において，現在のノードの管理領域とは，MD 木の特性に より，そのノードのすべての子孫ノードの管理領域を包含 した形状となっているため, 現在のノードの管理領域のみ を検証対象とすればよい。 Ra と交差する管理領域をもつ兄 弟ノードがある場合には, 登録している Io の部分木以外で $\mathrm{Ra}$ と交差する管理領域をもつノードが存在する，言い換え ると, 次回の連続的な検索時に, 現在登録している Io を根 とした部分木以外の範囲を探索しなければならない可能性 があるので, Io を現在のノードに再登録する必要がある。

連続的な検索時には, Anticipation( )で求めた Io を用い て SuccessiveSearch( )を実行し, 検索 Queryに該当するデ ータをDに登録してユーザに返す。SuccessiveSearch( )で は, Search()を実行する前に，与えられた Io が適切な頂点 ノードかどうか（すなわち，Io の管理領域が実際に R を完 全に包含しているかどうか）を判定し, 包含してない場合 は InitialSearch( )を実行する (S2 参照)。この処理により， 予測が完全に外れた場合には，根から検索を開始すること により, DIMD 木の検索コストの増加を抑制するために MD 木と同等の検索を実施する。また, $\operatorname{Search}($ )の実行後には, 戻り值 Io が適切な頂点ノードかどうか（すなわち, Ra を完 全に包含し, かつ Ra と交差する管理領域をもつ兄弟ノード がないか）を判定し，必要があれば適切なノードまで親ノ ードをたどる (S4 参照)。なお, 適切なノードが見つかれば, その時点で Io の決定を終了すため, 必ずしも毎回根までた どる必要はない。

理論的に, DIMD 木の最悪の場合では, Bentley の方式 の最悪時と同様に, 葉から根までたどった後に検索を実行 する場合が考えられる。検索コストとしては, 葉から根ま
でたどったコスト $+\mathrm{MD}$ 木の検索コストとなる。しかしな がら, この場合が起こりうる状態としては, 移動オブジェ クトが予測していた速度の限界を大幅に越えて移動した場 合や，もしくは移動オブジェクトの次の位置をピンポイン トで予測し，かつその予測が大きく外れてしまった場合の ように，移動オブジェクトが限界を超えた速度で移動した り，非常に精度の低い予測情報を与えられたりといった， 極めて特殊な場合しか考えられない。しかしながら, DIMD 木では, 移動オブジェクトの物理的・性能的限界より導き 出される数值を用いることにより, 前者が発生する可能性 を低くすることが可能である。一方, 後者が発生する場合 （すなわち，DIMD 木の予測が外れる場合）は，MD 木と同 様に根から検索を開始することで, 検索コストの悪化を抑 えている。この他に, 移動オブジェクトの予想が外れる場 合が多いときの判定として, SuccessiveSearch( )の実行に おいて根までたどる確率で判定する方式なども可能であ る。DIMD 木の検索コストについては，4 章のシミュレー ション実験で検証を行う。シミュレーション実験では, 仮 想的に最悪時の検索を実現し検証している。なお, 独立検 索の際には, その時の予測参照先を指し示す Io はクライア ントが一時的に保持しておき, InitialSearch()を実行する。 InitialSeach( )の終了時には, その戻り值で Io を更新せず に，一時的に保存していた Io を有効值とする。

\section{4. シミュレーション実験}

DIMD 木の有用性と特徵を検討するために, MD 木との 比較実験を行った。MD 木では, 移動オブジェクトの未来 の位置の予測や予測に基づいた検索などは実施していな い。したがって, MD 木の空閒範囲検索は, オリジナルの 設定, すなわち木の根から検索を開始させている。実験で は, データ構造の構築時間, データ構造に要求される記憶 容量, そして, 検索効率を比較検討している。なお, MD 木とDIMD 木の葉に格納されるオブジェクトのデータ数や 子ノードの数などの構造の特徵は同じに設定している。

〈4-1〉 実験条件 DIMD 木と MD 木には，2 次元点 データ（x,y）を入力データ（200,000 個）として, 同様の データセットを管理させる。最大子ノード数は 3 であり, 葉に格納されるオブジェクトのデータ数の最大值は 20 とす る。全データ空間を $(10,000 \times 10,000)$ の正方形とし, 1.0 $\times 1.0$ に正規化させている。管理させるオブジェクトの位置 は, 一様分布の乱数より生成させる。移動オブジェクトは, 速度 $\mathrm{V}\left(\mathrm{V}_{\mathrm{x}}, \mathrm{V}_{\mathrm{y}}\right)$ をパラメータとしてもつ 2 次元点データと する。シミュレーション実験では, 移動オブジェクトの数

表 $1 \mathrm{MD}$ 木と DIMD 木の構造

Table 1. MD-tree and DIMD-tree construction.

\begin{tabular}{|c|c|c|c|}
\hline & $\begin{array}{c}\text { construction } \\
\text { time (sec.) }\end{array}$ & node (\#) & leaf (\#) \\
\hline MD-tree & 1.71 & 8,788 & 11,857 \\
\hline DIMD-tree & 1.77 & 8,788 & 11,857 \\
\hline
\end{tabular}




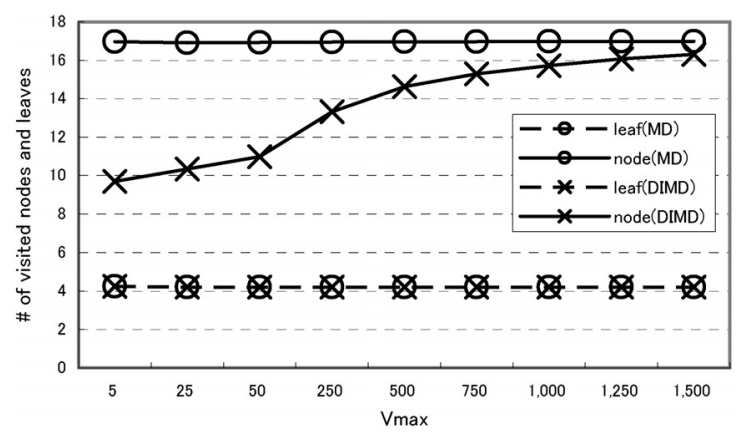

図 $6 \mathrm{MD}$ 木と DIMD 木の検索結果（予測誤差 : 無)

Fig. 6. Search performances of the MD-tree and the DIMD-tree (without expectation error).

は, データ構造内の静的オブジェクト（道路や建物などの 地図情報成分）の $10 \%$ （すなわち，20,000 個）としている。 移動オブジェクトは, 1 単位時間にランダムな方向に直線移 動を行い，1,000 単位時間経過させ， 1 単位時間ごとの移動 オブジェクトの検索結果の平均值をデータアクセス性能の 指標としている。各移動オブジェクトの速度は，1 単位時間 ごとに $[0, \mathrm{~V} \max ]$ の範囲内で与えられる。また, 移動オブ ジェクトの未来の位置十検索範囲の領域を Ra とすると, Ra の面積は(3)式で示される。なお, Vmax を移動オブジ エクトの最大速度， $2 \mathrm{r}$ を検索範囲の一辺の長さ， $\mathrm{E}$ を予測 の誤差とした。なお, 実験時では, Vmax と $\mathrm{E}$ を変動して 設定することにより，DIMD 木の検証を行っている。

$$
A_{R a}=4(E \cdot V \max +r)^{2}
$$

〈4·2〉実験結果 表 1 にDIMD 木と MD 木の構築時 間とデータ構造に要求される記憶容量の結果を示す。本実 験では，DIMD 木と MD 木に対して，200,000 個の入力デ 一タが一括に与えられている。表 1 より, DIMD 木に必要 となる記憶容量は, DIMD 木のノードと葉の数から換算す ると，MD 木とほぼ同様になることが推測できる。また， DIMD 木は MD 木より拡張したことにより，その構築時間 は MD 木の場合に比べ約 3.5\%増加している。

次に, 図 6 に空間範囲検索の結果を示す。この実験では, 空間範囲検索の一辺の長さを全データ空間の長さの $1 \%$ (す なわち, 検索範囲（正方形）の一辺の長さが 100）の大ささ とし，移動オブジェクトの未来予測に関して，予測の誤差 はないものとする。また, 通常, 移動オブジェクトの速度 は全データ空間の大きさに比べて小さいものであるが，こ こでは, 移動オブジェクトの速度 $\operatorname{Vmax}$ を試験的に増加さ せていった。このとき, $V \max$ が 1,500より大きい場合は, DIMD 木の直接参照先であるノードが根であるか，もしく は根に非常に近いため, DIMD 木と MD 木の検索性能は, ほぼ同じになる。したがって，図 6 では特徵が示されてい る範囲を取り上げている。図 6 より, DIMD 木の検索時に たどる探索ノード数は, MD 木のものより最大で約 $40 \%$ 削 減されている。また, 最小でも約 $2 \%$ 削減されており, 最悪 時でも MD 木とほぼ同じ性能となっている。これは, DIMD

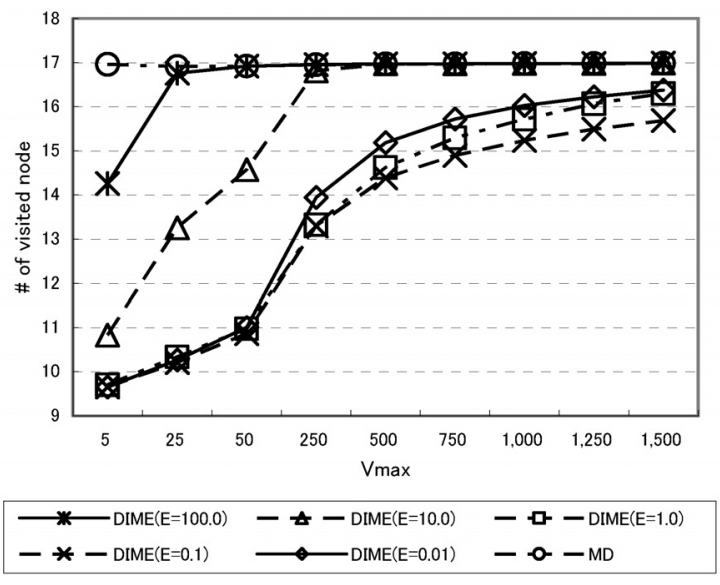

図 $7 \mathrm{MD}$ 木と DIMD 木の検索結果（予測誤差 $\mathrm{E}$ : 有）

Fig. 7. Search performances of the MD-tree and the DIMD-tree (with expectation error).

木の直接参照の機能によって, 内部ノードなどから検索を 開始することで検索時にたどるノード数の削減されている ことを示している。また, 検索対象となる探索葉数は, MD 木と同じになった。検索対象となる探索葉数は, 全体の根 から探索したとしても, また, 直接アクセスしたとしても, 検索時に検索対象となる葉の数に変化はないため, DIMD 木と MD 木は同じ数になっている。以上より, 予測に誤差 が無い場合では, DIMD 木の検索性能は, MD 木よりも効 率的であり, 最悪時でも, DIMD 木の検索性能は MD 木と 同様となることが確認できた。

また，図 7 に予測に誤差がある場合の実験結果を示す。 ここでは探索ノード数をとりあげている。図 7 では, 図 6 と同様の入力データを用いた上で, 未来予測に, 移動オブ ジェクトの速度に対する割合によって算出した誤差 $\mathrm{E}$ を与 えている。(3)式により導出した予測範囲は, 全方位への可 能性を考慮しているため, 実際の検索範囲に比べて比較的 に大きな範囲となる。 $\mathrm{E}$ を変動して実験した結果, それら の結果の特徴を表しているものの代表として, 誤差 E の割 合の最大值が $\{0.01,0.1,1.0,10.0,100.0\}$ の実験結果を図 7 に示している。また, 比較のために, 予測のない MD 木 (図 6 の結果) も示している。図 7 より, 移動オブジェクト の未来位置の予測に䛊差がある場合, DIMD 木の検索性能 は, 移動オブジェクトの速度と誤差の程度に依存している ことが確認できる。例えば，速度が大きくなるに従って， DIMD 木の結果が MD 木の結果に近接する傾向は図 6 と同 じである。一方, 誤差の大きさは速度に依存しているため, 速度が小さい場合には, 誤差の影響は小さいものになるが, 速度が大きくなると誤差の影響が結果に表れる。

誤差 $\mathrm{E}$ が 1.0 より大きい場合, 適切な予測範囲よりも大 きな範囲を予測することになり，範囲の大きな管理領域を もつノード, すなわち根に近いノードを直接参照先として 決定する可能性が高くなる。よって, E が大きいものほじ $\mathrm{MD}$ 木の結果に近くなる。なお, $\mathrm{E}$ が 1.0 より大きい場合に おける最悪のケースとは, 直接参照先として根が選択され 
表 $2 \mathrm{DIMD}$ 木，MD 木および Bentley 方式の特徴

Table 2. Characteristics of the DIMD, MD tees and Bentley method.

\begin{tabular}{|c|c|c|c|c|}
\hline & DIMD-tree & Bentley method & MD-tree & $\begin{array}{c}\text { DIMD-tree/Bentley method } \\
\text { (Worst Case) }\end{array}$ \\
\hline Anticipation transaction & 0 & $\times$ & $\times$ & $\begin{array}{c}\text { The case of a complete miss- } \\
\text { anticipation. }\end{array}$ \\
\hline $\begin{array}{c}\text { Destination of } \\
\text { the direct access }\end{array}$ & Leaf/Node & Leaf & $\times$ & Leaf \\
\hline Starting node of the searches & $\begin{array}{c}\text { Leaf/Node of the } \\
\text { direct access }\end{array}$ & $\begin{array}{c}\text { Leaf of the } \\
\text { direct access }\end{array}$ & $\begin{array}{c}\text { After the bottom-up-search from a } \\
\text { leaf to the root, the searches } \\
\text { re-start from the root }\end{array}$ \\
\hline
\end{tabular}

ることであり，言い換えると MD 木と同じ結果になること である。また， E が 1.0 より小さい場合，適切な予測範囲よ りも小さな範囲を予測することになり，範囲の小さな管理 領域をもつノード，すなわち葉に近いノードを直接参照先 として決定する可能性が高くなる。すなわち， E = 1.0 の場 合に直接参照先として指し示されるノードを根とした部分 木において，その部分木の根と葉の間にあるノードを指し 示すことになる。したがって, 確率的に比較的よい結果が 得られる可能性があり, 結果からもそのことが確認できた。 ただし， $\mathrm{E}=0.1$ よりも $\mathrm{E}=0.01$ の方が検索コストは高い。 これは，移動オブジェクトが実際に移動できる範囲よりも 小さい範囲を予測情報として与えられた場合, 直接参照先 の管理領域外を検索しなければならない可能性が発生す る。そのような場合では, DIMD 木は検索コストの悪化を 抑えるために，根から検索を実施する方式をここでは採用 している。したがって, E が 1.0 より小さくなればなるほど, 予測が外れて根から検索する機会が増えるため, 移動オブ ジェクトの速度が増加すると, $\mathrm{E}=0.01$ の方が $\mathrm{E}=0.1$ より も検索コストが高くなる傾向がある。しかしながら，本実 験の結果では, E が 1.0 より小さい場合においても, DIMD 木の検索コストは, $\mathrm{E}=1.0$ の場合と同程度であり, 最悪で も MD 木の検索コストよりも抑えられている。

もし，このような検索コストの増加を抑える方式を採用 していない場合, Eが 1.0 より小さい場合における最悪のケ 一スとは, 直接参照先として葉が選択されている状態で, 根付近まで親ノードをさかのぼった後に, 改めて根から MD 木と同様の探索を行うことである。この場合は，MD 木よ りも検索性能が悪化する可能性が考えられるが，その性能 の低下（アクセスノード数の増加）は, 理論的には最大で も木の高さ分のノードアクセスが加算されるにすぎない。

この問題を検証するために, 図 7 の実験環境において, DIMD 木, 葉から検索を開始する Bentleyの方式, MD 木, および（仮想的に実現した）最悪時の DIMD 木（DIMD 木 （worst）と記す）による検索ノード数の比較実験を行った。 Bentley 方式は, 常に前回の Query 要求時の移動オブジェ クトの位置を含む葉から検索を開始し, 空間範囲に対して 適切なノード（すなわち，検索対象として当てはまる部分 木の頂点ノード）まで親ノードをたどりながら検索を行う。 DIMD 木（worst）は，強制的に葉から根までさかのぼった 後に根から検索した結果である。なお, Bentley 方式の最悪

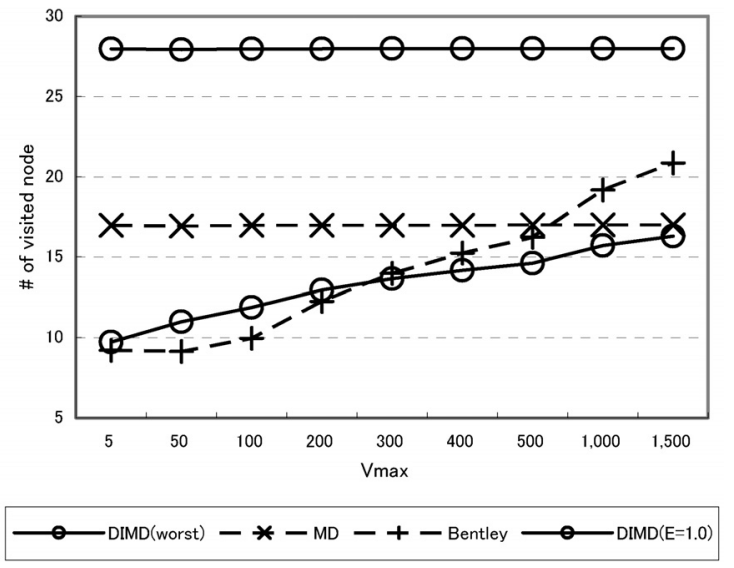

図 8 Bentley の方式と MD 木および DIMD 木（worst, $\mathrm{E}=1$ ) の検索結果

Fig. 8. Search performances of the Bentley's model, the MD-tree and DIMD-tree(worst, $\mathrm{E}=1$ ).

時の結果も, DIMD 木 (worst) と同じになる。これらの方 式を $\langle 4 \cdot 1\rangle$ 節の条件で構築して比較する。各方式の特徽を 表 2 にまとめる。各方式での検索の対象ノード数は, 一般 に次のような関係, DIMD 木 $/$ Bentley 方式 $<\mathrm{MD}$ 木 $<$ DIMD 木\&Bentley 方式 (Worst) が期待されるが，才 ブジェクトの状態, 検索条件, もしくは予測誤差により, DIMD 木, Bentley 方式, および MD 木との検索性能が逆 転する場合がありえる。これを検証するための実験結果を 図 8 に示す。図 8 より, DIMD 木は, 速度の上昇に比例し て検索コストは悪化するが, MD 木よりも常に低いコスト を保っている。一方 Bentleyの方式は, Vmax = 50 以降に 検索コストが上昇し, 実験值としては Vmax $=500$ 前後で MD 木よりも Bentley の方式のコストが悪化している。ま た, DIMD 木と Bentley の方式を比較すると, Vmax $\leqq 250$ 程度では, DIMD 木の方が Bentley の方式より最大で約 $17 \%$ 検索コストが多い。しかしながら，Vmax > 250 程度 では, DIMD 木の方が Bentley の方式よりコストが削減さ れているのが確認でき, 実験值では最大約 $22 \%$ の検索コス トの削減が確認できた。また, DIMD 木の最悪時の結果で ある DIMD 木 (worst) の検索時の探索ノード数は, MD 木 と比較して，(実際には起こる可能性は低いとしても）木の 高さ分（ここでは，11ノード分）の増加に抑えされている。 実験で得られた検索コストの結果をみると, DIMD 木の 
結果は，理論的な最悪值よりもよい值が示されており，経 験的に理論的な最悪值は表れにくいといえる。なお，予測 範囲と実際の位置が極めてずれている場合などのように， 直接参照の機能が有効に働かないと推測される際には, 第 3 章で述べたように，根から検索を開始する方法を本稿では 採用している。この他の方式としては, SuccessiveSearch( ) の S4 において，「Io の管理領域と R がまったくオーバーラ ップしないときには, InitialSearch( )を実行する」という 条件分岐を行うことで, 最悪時でも, DIMD 木は MD 木と 同等の効率とすることができる。なお，予想が外れる場合 が多いときの判定は, SuccessiveSearch( )の実行において 根までたどる確率で判定可能である。

以上の結果より，DIMD 木の検索性能は，MD 木や Bentley 方式などの従来法よりも有効性が高く, 最悪時でも コスト増が木の高さ程度に抑えられていた。したがって, DIMD 木の直接参照の機能により, MD 木の探索ノード数 の削減や Bentley 方式よりも高性能な検索の実施が実現さ れていることが確認できた。

\section{5. まとめ}

本論文では，GIS アプリケーションや GPS ナビゲーショ ンの分野において，移動オブジェクトからのデータアクセ スを高速化するための新しい方式を開発し, その手法を MD 木に適用して改良した新しい空間データ構造 DIMD 木を提 案した。DIMD 木は，移動オブジェクトの予測された未来 の位置情報に基づいて高速検索が可能であり，位置情報シ ステムやナビゲーションシステムに適用可能である。DIMD 木の性能をシミュレーション実験により検討した。DIMD 木に必要な記憶容量は，基になった $\mathrm{MD}$ 木とほぼ同じであ った。また，検索性能の比較では，予測が正確な場合にお いて, DIMD 木の検索時に探索されるノード数は, MD 木 の探索されるノード数の最大 $40 \%$ 程度削減されていた。ま た，位置予測に誤差がある際にも，誤差が小さい場合や誤 差の傾向によって, 予測が正確な場合と同程度の特性であ つた。また, 誤差の有無に共通して, 最悪時でも DIMD 木 の検索性能は MD 木と同程度であった。さらに Bentley 方 式の Bottom-up 検索と比較したところ, 位置予測に誤差が ある場合では，速度が小さいときには Bottom-up 検索が若 干優れていたが，速度がある閾值より大きくなると DIMD 木の方が検索コストは少なくなることが確認できた。これ らの実験結果より, DIMD 木は, 通常の木構造（すなわち, 根からデータを検索するようなデータ構造）や Bottom-up 検索のような従来法よりも効率的なデータアクセスが可能 なデータ構造であることが確認できた。DIMD 木の概念は， $\mathrm{R}$ 木や $\mathrm{KDB}$ 木などの他のデータ構造にも適用可能である。 今後の課題として, 移動オブジェクトの過去の履歴や軌跡 も管理するようにDIMD 木の拡張を検討している。

(平成 18 年 6 月 29 日受付, 平成 19 年 6 月 19 日再受付)

\section{文献}

(1) J. R. Driscoll, N. Sarnak, D. D. Sleator, and R. E. Tarjan : "Making Data Structure Persistent", J. Comp. \& Syst. Sci., Vol.38, pp.86-124 (1989)

(2) N. Sarnak and R. E. Tarjan : "Planar Point Location Using Persistent Search Tree”, Commun. ACM, Vol.29, No.7, pp.669-679 (1991)

（3）寺岡照彦・丸山 稔・中村泰明・西田正吾：「空間検索を効率化した 時空間デー夕管理構造の提案 - 多次元 Persistent Tree-」, 信学 論 D-II, Vol.J78-D-II, No.9, pp.1346-1355 (1995)

（4）中村泰明・出木原裕順:「時間属性を持った空間データの管理構造一 PMD 木一」, 情処学論, Vol.40, No.SIG5 (TOD2), pp.54-68 (1999)

(5) Webraska: http://www.webraska.com/, (2005)

(6) Y. Tao, J. Sun, and D. Papadias : "Analysis of predictive spatio-temporal queries", ACM Trans. Database Syst., Vol.28, No.4, pp.295-336 (2003)

(7) S. Saltenis, C. S. Jensen, S. T. Leutenegger, and M. A. Lopez : "Indexing the Position of Continuously Moving Objects", Proc. ACM SIGMOD, pp.331-342 (2000)

(8) Y. Tao, C. Faloutsos, D. Papadias, and B. Liu : "Prediction and indexing of moving objects with unknown motion patterns", Proc. ACM SIGMOD, pp.611-622 (2004)

(9) D. Pfoser, C. S. Jensen, and Y. Theodoridis : "Novel Approaches to the Indexing of Moving Object Trajectories", Proc. VLDB, pp.10-14 (2000)

（10）出木原裕順・中村泰明：「移動オブジェクトを管理する時空間データ 構造」, 電学論 C, 122-C, 6, pp.1052-1059 (2002-6)

(11) Y. Nakamura, S. Abe, Y. Ohsawa, and M. Sakauchi : "The MD-tree: An Efficient Data Management Structure for Spatial Objects", IEEE trans. KDE., Vol.5, No.4, pp.682-694 (1993)

(12) A. Guttman : "A Dynamic Index Structure for Spatial Searching", Proc. ACM SIGMOD, pp.47-57 (1984)

(13) N. Beckman, H. P. Kriegel, R. Schneider, and B. Seeger : " $\mathrm{R}^{*}$-trees: An Efficient and Robust access Method for Points and Rectangles", Proc. ACM SIGMOD, pp.322-331 (1990)

(14) J. T. Robinson : "The KDB Tree: A Search Structure for Large Multidimensional Dynamic Indexes", Proc. ACM SIGMOD, pp.10-18 (1981)

(15) J. L. Bentley : "K-d trees for Semidynamic Point Sets", Proc. ACM Symp. on $6^{\text {th }}$ SCG, pp.87-197 (1990)

出木原 裕 順 (正員) 1998 年広島市立大学情報数理学科卒 業。2000 年同大学院情報科学研究科修士課程 修了。同年同博士後期課程入学。2002 年広島 国際大学人間環境科学部感性情報学科助手。 2003 年広島市立大学大学院情報科学研究科博 士後期課程修了 (博士 (情報工学) )。2004 年 広島国際大学社会環境科学部情報通信学科講 師。現在に至る。時空間データ構造, 移動オブ ジェクト等の研究に従事。IEEE 等各会員。

中 村 泰 明 (非会員) 1977 年大阪大学制御工学科卒業,

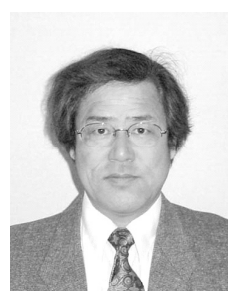
1979 年同博士前期課程修了。同年三菱電機株 式会社入社。以来, 1994 年まで同中央研究所 にて, 画像処理, VR, 空間データ構造, 地理 情報システム等の研究に従事。1994 年広島市 立大学情報科学部情報数理学科教授。2006 年 日本情報通信研究開発機構技師長兼 TTT 株式 会社 SRI 部長, 現在に至る。工学博士 (東京大

学)。IEEE, 電子情報通信学会, 情報処理学会会員。 